\title{
Calbindin D-28k and parvalbumin immunoreactivity in the frontal cortex in patients with frontal lobe dementia of non-Alzheimer type associated with amyotrophic lateral sclerosis
}

\author{
I Ferrer, T Tunón, M T Serrano, R Casas, S Alcántara, M J Zújar, R M Rivera
}

\begin{abstract}
The morphology and distribution of local-circuit neurons (interneurons) were examined, by calbindin D-28k and parvalbumin immunocytochemistry, in the frontal cortex (area 8) in two patients with frontal lobe dementia of nonAlzheimer type associated with classical amyotrophic lateral sclerosis (ALS), and in seven normal cases. The density of calbindin D-28k immunoreactive cells was dramatically reduced in ALS patients, but the density of parvalbuminimmunoreactive neurons was preserved. Decreased density of calbindin D-28kimmunoreactive neurons, which are mainly located in the upper cortical layers, may interfere with the normal processing of cortico-cortical connections, whereas integrity of parvalbuminimmunoreactive cells may be associated with the preservation of the major inhibitory intracortical circuits in patients with frontal lobe dementia.
\end{abstract}

\section{(F Neurol Neurosurg Psychiatry 1993;56:257-261)}

Intellectual impairment and dementia occur in some patients with classic amyotrophic lateral sclerosis (ALS; motor neuron disease)..$^{1-8}$ Clinical symptoms and signs conform with different prefrontal syndromes, ${ }^{9}$ whereas morphological lesions are characterised by atrophy of the frontal (and temporal) lobes, neuron loss and spongiosis in layers II and III, together with gliosis of the cerebral cortex, and myelin pallor and gliosis of the subcortical white matter. These abnormalities are similar in frontal lobe dementia of nonAlzheimer type in older people. ${ }^{10-12}$

Golgi studies have shown degeneration of pyramidal and non-pyramidal (local-circuit) neurons in layers II and III, ${ }^{513}$ which suggest that, in addition to neuron loss, abnormalities of surviving cells in the frontal cortex may contribute to the pathology in patients with frontal lobe dementia.

In this study we investigate the vulnerability of different types of intracortical local-circuit neurons by means of parvalbumin and calbindin immunocytochemistry in two patients with mental deterioration and dementia associated with ALS. We chose this method because calbindin D-28k and parvalbumin are calcium-binding proteins which are found in the cerebral cortex and hippocampus in different populations of local- circuit neurons which use gamma-aminobutyric acid (GABA) as a neurotransmitter. ${ }^{14-24}$

\section{Patients and methods}

The patients were two women aged 38 and 71 years. Both conformed to previous clinical descriptions of dementia associated with ALS. ${ }^{1-81325}$

The patients died as a result of bilateral bronchopneumonia 4 and 2 months, respectively, from the beginning of the motor signs.

The brains were removed less than 6 hours (first case) and 2 hours (second case) after death, immediately fixed in fresh $5 \%$ formalin (first case) or $4 \%$ paraformaldehyde (second case) for about four weeks, and later processed for microscopical examination following currently used neuropathological methods. The neuropathological findings were similar in both patients and included marked neuron loss, gliosis and chromatolysis of the remaining nerve cells in the hypoglossal nucleus, demyelination of the pyramidal tracts at the level of the bulbar pyramids and degeneration of layer $\mathrm{V}$ pyramidal cells in the motor cortex. In addition, the frontal lobes were atrophic due to nerve cell loss and spongiosis in layers II and III, together with reduction of the subcortical white matter. Astrocytic gliosis in the cerebral cortex and white matter of the frontal (and temporal) lobes were found. Cortical lesions were more severe in the first patient.

Neurofibrillary degeneration, senile plaques, and granulovacuolar degeneration were not seen. Pick bodies were absent, and Lewy bodies were not observed in the substantia nigra and cerebral cortex. Intraneuronal argyrophilic grains were not found in the cerebral cortex and hippocampus.

Samples of the left frontal lobe cerebral cortex were obtained on the second day of fixation, protected with $30 \%$ saccharose, frozen and stored at $-80^{\circ} \mathrm{C}$ until use.

Control specimens were from seven patients aged 19-77 years mean (SD) 46 $(21.5)$ with no neurological, metabolic or malignant disease. Technical procedures to minimise methodological pitfalls, including short interval between death and tissue processing, use of fresh fixative solutions, and reduction of the time of fixation for immunocytochemistry to 48 hours, were similar in ALS patients and controls.

Sections $50 \mu$ thick were obtained with a freezing microtome and processed free-float- 
Figure 1 Calbindin D28k-immunoreactive neurons in the frontal cortex (area 8) in one control $(A$ and $B)$, and in two patients with intellectual impairment associated with ALS (C and D). Decreased immunoreactivity (lower numbers of neurons and reduced dendritic arbors) are observed in these patients. $A$ and $B$ : control aged 68 years; $C$ : second case; D: first case. $M O L$ : molecular layer; II, III: cellular layers. $A-C$ : bar $=$ $200 \mu ; B$, bar $=100 \mu$.

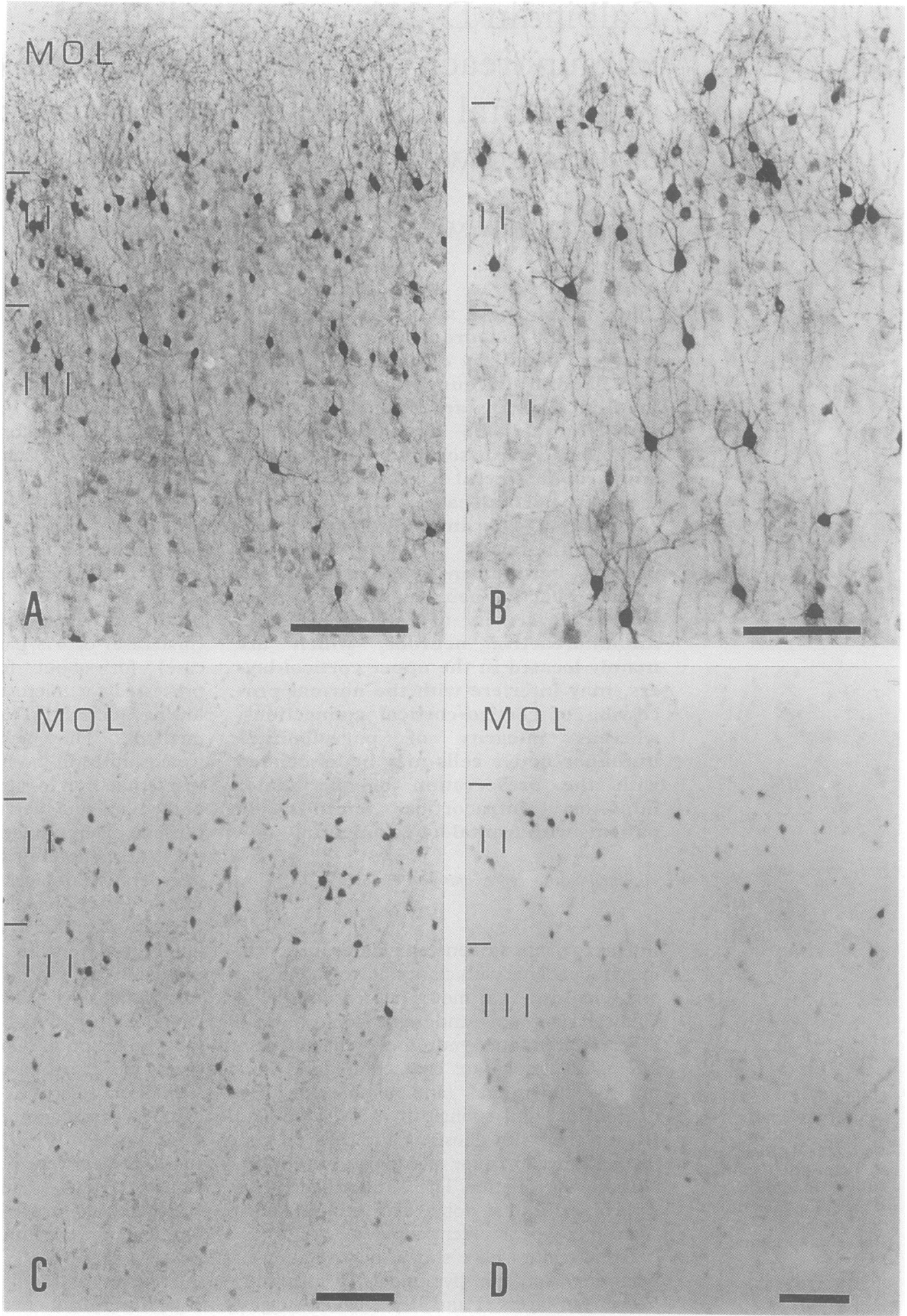

ing to demonstrate calbindin and parvalbumin immunoreactivities using the avidin and biotin (ABC, Vector Labs) method. Well characterised monoclonal antibodies ${ }^{21}$ against calbindin D-28k (purified from chicken gut) and parvalbumin (purified from carp muscle) (Sigma clones CL-300 and PA-235; Mouse IgG1) were used at dilutions $1 / 800$ and $1 / 2000$ respectively.

Calbindin D-28k and parvalbuminimmunoreactive neurons were separately counted in ten vertical columns $1200 \mu$ wide from the whole cortical thickness in the crown of area 8 in every case, and their mean (SD) densities were expressed per $\mathrm{mm} .^{2}$

\section{Results}

Calbindin D-28k-immunoreactive cells were small multipolar neurons with ascending dendrites in the molecular layer, and small bitufted cells and double bouquet neurons in layers 
Figure 2 Parvalbuminimmunoreactive neurons in the frontal cortex (area 8) in one control (aged 68 vears) $(A)$ and in one patient with dementia associated with $A L S$ (case 1) (B). PARV immunoreactivity is preserved in the patient with dementia. III-VI: cellular layers III-VI. Bar $=200 \mu$.

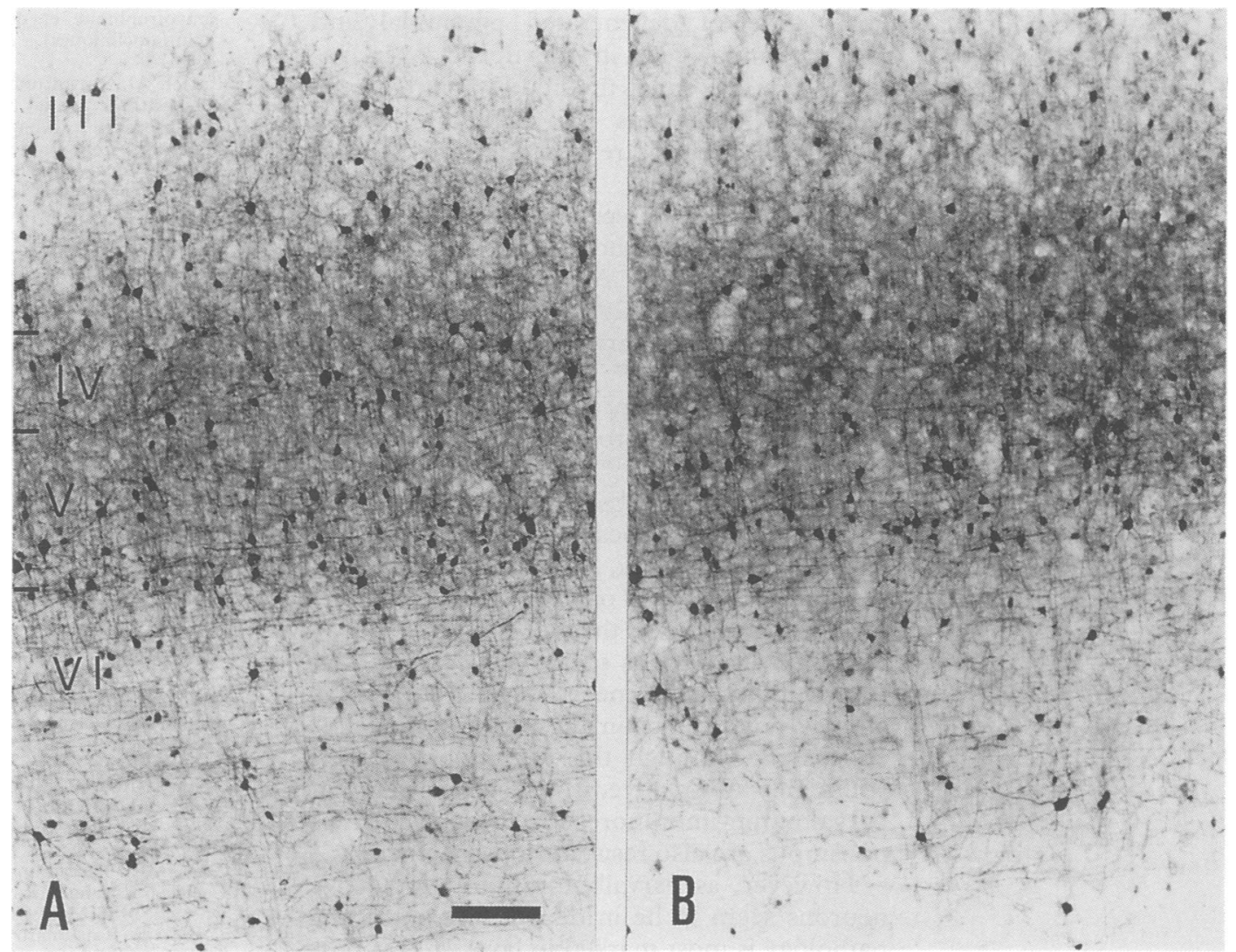

II and III (fig $1 \mathrm{~A}$ and B). Small numbers of immunolabelled cells, most of them multipolar, were also seen in layers V and VI. Pyramidal cells were only very weakly immunolabelled in layers II and III. Homogeneous labelling of pyramidal and non-pyramidal neurons in these layers did occur, however, when the primary antibody was used at dilutions lower than those described in Methods.

Calbindin D-28k immunoreactivity was drastically reduced in the two patients with ALS and mental impairment (fig $1 \mathrm{C}$ and $\mathrm{D}$ ). The number of immunolabelled neurons was decreased, and most of the remaining neurons had very short immunoreactive dendritic arbors. Significant differences in the density of calbindin D-28k-immunoreactive cells were found between patients with dementia and controls (ALS patients with dementia: $22 \cdot 4(9 \cdot 1)$ cells per $\mathrm{mm}^{2}$; controls: $68 \cdot 5(9 \cdot 1)$; Mann Whitney U test, 2 -tailed $\mathrm{p}<0.001$ ).

Parvalbumin-immunoreactive cells were multipolar neurons found in all cortical layers except the molecular layer, and predominating in layers III, IV and V. Parvalbumin immunoreactivity was preserved in patients with ALS, and the morphology and distribution of parvalbumin-immunolabelled cells were similar in ALS patients and controls (fig $2 \mathrm{~A}$ and $\mathrm{B}$ ). Furthermore, quantitative studies disclosed no significant differences in the density of parvalbumin-immunoreactive cells between ALS patients with dementia and controls $(110.8(19.3)$ and $93.6(14.6)$ cells per $\mathrm{mm}^{2}$ respectively; $\mathrm{p}>0 \cdot 1$ Mann-Whitney U test).

\section{Discussion}

The morphology and distribution of calpresent series are similar to those described in other observations. ${ }^{16-18} 24$ 26-29 However, in contrast to the temporal lobe, ${ }^{29}$ multipolar neurons of layer II with very long descending dendrites and horizontal neurons of the molecular layer were not labelled in the frontal cortex, suggesting that calbindin D-28k immunoreactivity in the human neocortex is subject to regional variations.

Parvalbumin-immunoreactive neurons in this study were similar to basket neurons and chandelier cells previously described in the neocortex and hippocampus. ${ }^{162830-34}$

The density of calbindin D-28k-immunoreactive neurons was reduced in ALS patients, but the density of parvalbuminimmunoreactive neurons was preserved. Although our quantitative data do not take into account the cortical atrophy which could lead to a compacting down of surviving cells, this probably does not affect the outcome of the comparisons between ALS patients and controls. On the contrary, because of cortical atrophy the density of cells in ALS with dementia will be artificially raised, and, for this reason, the degree of actual loss of calbindin D-28k-immunoreactive cells is underestimated in our patients.

Whether loss of immunoreactivity reflects a reduction in the number of neurons cannot be assessed on the basis of the immunocytochemical data alone. Nissl preparations, however, demonstrate loss of neurons in the upper layers. This feature together with the bindin D-28k-immunoreactive cells in the 
observation of degenerated pyramidal and non-pyramidal cells in the upper layers, as seen with the Golgi method, ${ }^{13}$ points to the likelihood that loss of calbindin D-28k immunoreactivity is related to an actual loss of neurons.

Although not universally accepted, ${ }^{35}$ similar findings are found in the neocortex of most patients with Alzheimer's disease in which calbindin D-28k immunoreactivity is decreased whereas parvalbumin immunoreactivity is preserved. ${ }^{36-39}$ Parvalbumin immunoreactivity is, however, decreased in a number of patients with, probably, very advanced Alzheimer's disease. ${ }^{384041}$

Together, these observations indicate that vulnerability of local-circuit neurons in frontal lobe dementia, and in Alzheimer's disease, might depend on the calcium-binding protein content, and that the presence of parvalbumin in neurons seems to decrease their susceptibility to neuro-degeneration, as already pointed out in the kindling model of epilepsy. ${ }^{42}$ Although this latter possibility is still highly speculative, it is worth noting that parvalbumin-immunoreactive cells in the hippocampus are also resistant to ischaemia. ${ }^{43}$

However, as parvalbumin-immunoreactive neurons seem to be in deeper layers and the pathology is most marked in layer II, it is possible that no selective neuronal damage, on the basis of differential calcium-binding protein content, occurs in ALS patients with dementia. Calbindin D-28k-immunoreactive neurons could be more affected simply through anatomical considerations.

On the basis of their typology and distribution in layers II and III, which are the main source and the main recipient of cortico-cortical projections, ${ }^{44}$ we propose that decreased numbers of calbindin D-28k-immunoreactive local-circuit neurons in the neocortex may interfere with the operations of contralateral and ipsilateral cortico-cortical connections. These abnormalities may contribute to the development of neurological deficits.

On the other hand, since fast-spiking cells in rat hippocampus contain parvalbumin, ${ }^{45}$ and basket neurons and chandelier cells (which are the main parvalbumin-containing neurons in the neocortex and hippocampus) establish synapses with the perikaryon and proximal segment of the axon pyramidal cells, ${ }^{4647}$ it is feasible that these neurons are the most potent inhibitory cells of the cerebral cortex. Preservation of parvalbuminimmunoreactive cells therefore may be associated with the preservation of the major inhibitory circuits in the neocortex in patients with frontal lobe dementia.

This work was supported by a grant FIS $90 \mathrm{E} 1263$ and the Government of Navarra. RM Rivera is a recipient of a grant from CIRIT. We are indebted to $T$ Yohannan for editorial assistance.

1 Michaux A, Samson M, Harl JM, Gruner J. Evolution dèmentielle de deux cas de sclèrose latérale amydèmentielle de deux cas de sclèrose latérale amyotrophique accompagn
(Paris) 1955;92:357-67.

2 Delay J, Brion S, Escourolle R, Marty R. Sclérose latèrale amyotrophique et dèmence (A propos de deux cas anatomocliniques). Rev Neurolog (Paris) 1959;100: 191-204.

3 Hudson AJ. Amyotrophic lateral sclerosis and its association with dementia, parkinsonism and other neurological disorders: a review. Brain 1981;104:217-47.

4 Mitsuyama Y. Presenile dementia with motor neuron disease in Japan: clinico-pathological review of 26 cases. $\mathcal{F}$ Neurol, Neurosurg Psychiatry 1984;47:953-9.

5 Horoupian DS, Thal L, Katzman R, et al. Dementia and motor neuron disease: morphometric, biochemical and Golgi studies. Ann Neurol 1984;16:305-13.

6 Morita K, Kaita H, Okeda T, Namba M. Presenile dementia combined with amyotrophy: a review of 34 Japanese cases. Arch Gerontol Psychiatry 1987;6:263-77.

7 Gilbert JJ, Kish SJ, Chang LJ, Hornyekiewicz O. Dementia, parkinsonism and motor neuron disease: Dementia, parkinsonism and motor neuron disease:
Neurochemical and neuropathological correlates. Ann Neurol 1988;24:688-91.

8 Neary D, Snowden JS, Mann DMA, Northern B, Goulding PJ, Macdermott N. Frontal lobe dementia and motor neuron disease. $\mathcal{f}$ Neurol, Neurosurg Psychiatry 1988;51:353-61.

9 Fuster JM. The prefrontal cortex. Anatomy, physiology, and neuropsychology of the frontal lobe. New York: Raven Press, 1989.

10 Brun A, Frontal lobe degeneration of non-Alzheimer type. I.-Neuropathology. Arch Gerontol Geriatry 1987;6: 193-208.

11 Neary D, Snowden JSS, Northern B, Goulding P. Dementia of frontal lobe type. $₹$ Neurol, Neurosurg Psychiatry 1988;51:353-61.

12 Knopman DS, Mastri AR, Frey WH, Sung JH, Rustan T. Dementia lacking distinctive features: a common nonAlzheimer degenerative dementia. Neurol 1990;40: 251-6.

13 Ferrer I, Roig C, Espino A, Peiró G, Matias Guiu X. Dementia of frontal lobe type and motor neuron disease. A Golgi study of the frontal cortex. $\mathcal{F}$ Neurol, Neurosurg Psychiatry 1991;54:932-4.

14 Celio MR. Parvalbumin in most gamma-aminobutyric acid-containing neurons of the rat cerebral cortex. Science 1986,231:995-7.

15 Kosaka T, Katsumaru H, Hama K, Wu JY, Heizmann $\mathrm{CW}$. GABAergic neurons containing the $\mathrm{Ca} 2=$ binding protein parvalbumin in the rat hippocampus and ing protein parvalbumin in the rat hippocan

16 Hendry SH, Jones EG, Emson DC, Lawson DE, Heizmann CW, Streit P. Two classes of cortical GABA Heizmann CW, Streit P. Two classes of cortical GABA neurons defined by differential calcium binding protei
immunoreactivities. Exper Brain Res 1989;76:467-72.

17 Demeulemeester H, Vandesande P, Orban GA, Brandon $\mathrm{C}$, Vanderhaeghen JJ. Heterogeneity of GABAergic cells in the cat visual cortex. $\mathcal{f}$ Neurosci $1988 ; 8$ :988-1000.

18 Demeulemeester $H$, Vandesande F, Orban GA, Heizmann CW, Pochet R. Calbindin D-28k and parvalbumin immunoreactivity is confined to two separate neuronal subpopulations in the cat visual cortex, whereas partial coexistence is shown in the dorsal geniculate nucleus. Neurosci Lett 1989;99:6-11.

19 Kosaka T, Heizmann CW, Selective staining of a population of parvalbumin-containing GABAergic neurons in tion of parvalbumin-containing GABAergic neurons in
the cerebral cortex by lectins with specific affinity for the cerebral cortex by lectins with specific affinity for terminal

20 Kosaka T, Heizmann, CW, Barnstable CJ. Monoclonal antibody VC1.1 selectively stains a population of GABAergic neurons containing the calcium-binding protein parvalbumin in the rat cerebral cortex. Exper Brain Res 1989;78:43-50.

21 Celio MR. Calbindin D-28K and parvalbumin in the rat nervous system. Neurosci 1990;35:375-475.

22 van Brederode JFM, Mulligan KA, Hendrickson AE. Calcium-binding proteins as markers for subpopulations of GABAergic neurons in monkey striate cortex. $\mathcal{f}$ Comparative Neurol 1990;298:1-22.

23 Kosaka T, Isogai K, Barnstable CJ, Heizmann CW, Monoclonal antibody HNK-1 selectively stains a subpopulation of GABAergic neurons containing the calcipopulation of GABAergic neurons containing the calci-
um-binding protein parvalbumin in the rat cerebral um-binding protein parvalbumin in the
cortex. Experim Brain Res 1990;82:566-74.

24 Demeulemeester H, Arcknes L, Vandesande F, Orban GA, Heizmann CW, Pochet R. Calcium-binding proteins and neuropeptides as molecular markers of GABAergic interneurons in the cat visual cortex. Experimen Brain Res 1991;84:538-44.

25 Brownell B, Oppenheimer DR, Trevor-Hughes J. The central nervous system in motor neurone disease. $f$ of Neurol, Neurosurg Psychiatry 1970;33:338-57.

26 DeFelipe J, Hendry SHC, Jones EG. Synapses of doublebouquet cells in monkey cerebral cortex visualized by calbindin immunoreactivity. Brain Res 1989;503:49-54

27 DeFelipe J, Hendry SHC, Hashikawa T, Molinari M, Jones EG. A microcolumnar structure of monkey cereJones EG. A microcolumnar structure of monkey cere-
bral cortex revealed by immunocytochemical studies of double bouquet cell axons. Neurosci 1990;37:655-73.

28 van Brederode JFM, Helliesen MK, Hendrickson AE. Distribution of calcium-binding proteins parvalbumin Distribution of calcium-binding proteins parvalbumin
and calbindin $\mathrm{D}-28 \mathrm{~K}$ in the sensorimotor cortex of the and calbindin $\mathrm{D}-28 \mathrm{~K}$ in the

29 Ferrer I, Tuñón T, Soriano E. del Rio A, Iraizoz I, Fonseca M, Guionnet N. Calbindin immunoreactivity in normal human temporal neocortex. Brain Res

30 DeFelipe J, Hendry SHC, Jones EG. Visualization of 
chandelier cell axons by parvalbumin immunoreactivity in monkey cerebral cortex. Proc Nat Acad Sci USA 1989;86:2093-7.

31 Blümcke I, Hof PR, Morrison JH, Celio MR. Distribution of parvalbumin immunoreactivity in the visual cortex of the old world monkeys and humans. $\mathcal{f}$ Comparative Neurol 1990;301:417-32.

32 Lewis DA, Lund JS. Heterogeneity of chandelier neurons in monkey neocortex: corticotropin-releasing factor- and parvalbumin-immunoreactive populations. Comparative Neurol 1990;293:599-615.

33 Nitsch $R$, Soriano $E$, Frotscher $M$. The parvalbumin-containing nonpyramidal neurons in the rat hippocampus. taining nonpyramidal neurons in the rat hip

34 Soriano E, Nitsch R, Frotscher M. Axo-axonic chandelier cells in the rat fascia dentata: Golgi-electron microscopy
and immunocytochemical studies. 7 Comparative Neurol and immunocytoc

35 Iacopino AM, Christakos S. Specific reductions of calcium-binding protein (28-kilodalton calbindin-D) gene expressions in aging and neurodegenerative diseases. Pro Nat Acad Sci USA 1990;87:4078-82.

36 Ichimiya Y. Emson, Mountjoy CQ, Lawson DEM, Heizmann CW. Loss of calbindin-28K immunoreactive neurons from the cortex in Alzheimer-type dementia. Brain Res 1989;475:156-9.

37 Hof PR, Cox K, Young WG, Celio MR, Rogers J, Morrison JH. Parvalbumin-immunoreactive neurons in the neocortex are resistant to degeneration in the neocortex are resistant to degeneration in 50:451-62.

38 Ferrer I, Soriano E, Tunoon T, Fonseca M, Guionnet N. Parvalbumin immunoreactive neurons in normal human temporal neocortex and in patients with Alzheimer's disease. F Neurolog Sci 1991;106:135-41

39 Ferrer I, Tuñón $\mathrm{T}$. Soriano $\mathrm{E}$, del Rio A, Iraizoz I, Fonseca M, Guionnet N. Calbindin immunoreactivity in the temporal neocortex in patients with Alzheimer's disease. Clin Neuropathol (in press).

40 Arai H, Emson PC, Mountjoy CO, Carasso LH, Heizmann CW, Loss of parvalbumin-immunoreactive neurons from cortex in Alzheimer's disease dementia. Brain Res 1987;418:164-9.

41 Satoh J, Tabira T, Sano M, Nakayama H, Tateishi J. Parvalbumin immunoreactive neurons in the human central nervous system are decreased in Alzheimer's disease. Acta Neuropathologica (Berlin) 1991;81:388-95.

42 Kamphuis W, Lopes da Silva FH. The kindling model of epilepsy: the role of GABAergic inhibition. Neurosci Res epilepsy: the role

43 Nitsch C, Scotti A, Sommacal A, Kalt G. GABAergic hippocampal neurons resistant to ischemia-induced neuronal death contain the $\mathrm{Ca}++$ binding protein parvalbumin. Neurosci Lett 1989;105:263-8.

44 Jones EG. Laminar distribution of cortical efferent cells. In: Peters A, Jones EG, eds. Cerebral cortex, vol 1 . Cellular components of the cerebral cortex. New York: Raven Press, 1984:521-53.

45 Kawaguchi Y, Katsumaru H, Kosaka T, Heizmann CW, Hama K. Fast-spiking cells in rat hippocampus (CAl region) contain the calcium-binding protein parvalbumin. Brain Res 1987;416:369-74.

46 Peters A. Chandelier cells. In: Peters A, Jones EG, eds. Cerebral cortex, vol 1. Cellular components of the cerebral

47 Jones EG, Hendry SHC. Basket cells. In: Peters A, Jones EG eds. Cerebral cortex, vol 1. Cellular components of the cerebral cortex. New York: Raven Press, 1984:309-36. 